\title{
The Use of Flipped Classroom in Teaching Writing: An Experimental Study
}

\author{
Mandala Putra*
}

\author{
Universitas Negeri Padang, Padang, Indonesia \\ Email:mandalarambe@gmail.com
}

\begin{abstract}
The purpose of this research is to investigate the influence of flipped classroom on the ability of the students to write descriptive text. This research used a quasi- experimental research as a research design. The tenth grade students of SMAN 1 Kutacane were the population of this research. Cluster random sampling used to select the sample. There were 59 students to be the sample of this research. Flipped classrom was used in experimental class and conventional technique was used in control class. T-test was used to analyze the data. The results found that there was a significant difference in the average of students' writing score in experimental class (85. 20) and control class (65.15). In short, flipped classroom provides a significant effect than conventional technique on the ability of the students to write descriptive text.
\end{abstract}

Keywords: Flipped classroom, writing, descriptive text

\section{INTRODUCTION}

Writing is one of the product skills that should be mastered by students in senior high school because this language skill is basic competency in English syllabus. The purpose is to achieve students communicative competence in written form. The students write various types of texts in different purposes. One of those texts is a descriptive text. Priyana [1] states that a descriptive text is a text type which represents the detail characteristics of a person, place, and object or event. The students are asked to describe something that is familiar with them. However, the students study English subject two hours in a week so that they have not enough time to develop their skill well in the classroom. Besides, writing is a skill that needs process so that they have to need a lot of time to learn. According to Oshima and Hogue [2] state that writing is a process not a product. When the students write a text, they are always possible to review and revise it continuously. This process needs a lot of time. Therefore, the English teachers must find an effective technique to deliver their materials in a short time. The technique is flipped classroom.

Flipped calssroom is a technique that use a video, slide presentations, reading materials and so forth from the teachers that are delivered through online system such as Whatsapp in outside of the classroom. Then, the students do the task as homework at home so that they are more active in learning, and they are able to overcome their problems in group activities in the classroom. As stated by Ekmekci [3], flipped classroom engages the students in active learning by studying in groups or individually. This technique provides the opportunity for the teachers to optimize the time to communicate with the students in the classroom intensively [4].

In addition, flipped classroom applies 21 st century skills. The students can use their critical thinking and problem solving skills when the teachers give them a task at home. Meanwhile, the students can communicate and discuss their tasks in pair or group in the classroom. They are also expected to be creative students to create their task by utilizing technology. Then, Çevikbaş and Argün [5] explain that the higher-order thinking skills of the students improves by implementing flipped classroom. They are able to use their higher levels of cognitive domain such as applying, analyzing, evaluating, and creating in the process of writing.

There are several studies relate to this research. First, Mervat Abd Elfatah and Ali Said Ahmed [6] conducted a research at Qassim University in Saudi Arabia in teaching writing of essay. The result indicated that the experimental students performed better on the writing essay than the control students. This research also used the same treatment that was flipped classroom; however the sample and the dependent variable were different. The sample of this research was the students in senior high school, and the dependent variable was writing of descriptive text.

Second, Rida Afrilyasanti, Bambang Yudi Cahyono and Utari Praba Astuti [7]. The results showed that there 
was a significant difference on the students' post-test score between the experimental and control groups.

Third, Fatemeh Soltanpour and Mohammadreza Valizadeh [8] also had investigated a research. This study was conducted at EFL learning institute in Iran in teaching argumentative essay. The findings of this study showed that the flipped calssroom improved students' writing quality more than the traditional technique.

Considering the explanation above, this research conducted to investigate the effect of flipped classroom on the ability of the students to write descriptive text at SMAN 1 Kutacane for the tenth grade students of science class in 2020/ 2021 academic year. This school was chosen because this area has good internet access to conduct this research and the students have smartphone.

\section{THEORETICAL REVIEW}

\subsection{Writing}

Writing has significant effect in enhancing communicative competence of learning English language that should be developed by the students because it is important[9]. Besides, writing is a process to express someone's thoughts and feelings into the written form. Brown [10] states that writing is a thinking process. Therefore, the students should generate their ideas and express them into a good writing so that it is easily for the readers to understand.

To make a good writing, the students must follow the process of writing. There are several steps of writing process, they are: prewriting, writing the first draft, revising, editing and proofreading [9]. First, there are five techniques in prewriting : (1) free writing, (2) questioning, (3) making a list, (4) clustering, and (5) preparing a scratch outline. With those techniques, they support the students to get ideas and develop a topic and find words on paper and also assist the learners to express about and create material because they are the important part of writing process. Second, the students need to prepare writing extra ideas in details about what they want to write, when the students write the first draft, and they do not need to take time to correct their first draft. Third, the students must to rewrite their writing to make it be better. The process of revision is divided into two steps, they are revising content and sentences. Fourth, editing means the students edit or check their writing for mistakes in grammar, punctuation, usage, and spelling.

There are three steps in teaching writing in the classroom. The first step (pre-writing), the students generate their ideas about the topic that will be written. According to Lindsay and Knight [11], the teacher sets the task, predicts the audience, brainstorms students' ideas, and decides topics. The second step is whilst writing in which when the students write their first draft, they should pay attention to the purpose of the writing, generic structure, and the language features of the text. Lindsay and Knight [11] explain that the teacher guides the students to write their draft, edit and rewrite their writing. The last step is post-writing. The teacher gives comments to the students' writing that aims to evaluate their writing and let them know which parts of their writing that should be developed for their further writing. To sum up, teaching writing in 2013 curriculum for senior high school requires the students to learn more by themselves, and the teacher acts as a facilitator.

\subsection{Descriptive Text}

According to Gerrot and Wignell [12], descriptive text is type of text which is purposed to represent particular people, places or things. The purpose of the text is to describe a particular person, place, or thing in details about how something or someone looks like.

There are two parts of generic structure of descriptive text. According to Wardani et al [13], generic structure of descriptive text are identification and description. Identification introduce subject or thing that will be described that is in the first paragraph. Description is a brief details information about the subject. The description can be physical appearance of the subject, the qualities of the subject, excellence or value, and other characteristics of the subject that is unique that the subject has. In addition, there are some language features of descriptive text such as: using specific participant, adjective, simple present tense, and action verbs.

\subsection{Flipped Classroom}

Flipped classroom is a new technique in which this technique is the opposite of conventional technique. The technique requires the students to learn the lesson materials at home through application and practice by using videos or others online materials that are sended by the teachers, then the students complete the task in the classroom. In this condition, the teachers have a lot of time to interact with the students to help them to improve their competence about the materials. Breztmann [15] states that flipped classroom is the opposite of conventional technique where the students get the materials outside of the classroom by some online devices such as reading or lecture videos or others, and then in the inside of the classroom is used to do the task through some strategies such as problemsolving, discussion or debates.

The flipped classroom changes the learning model from passive to active learning to focus on higher order thinking skills such as applying, analyzing, evaluating and creating that are proposed by Krathwohl [16] that 
revises the stages of the Bloom Taxonomy. These stages are done when the students are inside of the classroom.

By using flipped classroom, teachers change the model of learning from a large group learning into the individual learning by using several technologies such as video, a course management website, and so forth. Teachers can create their own videos or others online materials, or take the sources from the internet sites [17]. By applying this technique, teachers give the students a lot of time to integrate and apply their knowledge, variety of student-centered, active learning strategies to complete the task with classmates. Teachers also can use the time to check the students' understanding about the material and help them to improve their competence in doing the task by giving individual feedback.

In conclusion, flipped classroom is an effective technique that allow the students to learn individually through the online learning materials such as reading text or articles, video learning or presentation slide, and others that delivered by the teacher to online media such as Facebook, Youtube, Google Drive, and WhatsApp group and so forth [17].

There are some steps in implementing flipped classroom. First, the teachers create the online materials or they can take from the other sources. The teachers are required to create a great and interesting materials which can improve the teaching process. Second, teachers share the learning material to the students through online media. Teachers upload the learning material on a online class such as Google Drive, Facebook, WhatsApp group, Twitter, and so forth. Then, the students can download the learning material and learn it at home before coming to the classroom. The students are free to choose where and when they want to study that make them comfortable. They can study the material by themselves, friends or parents. They can choose any device to read or watch the learning material from their smartphone or their laptop. They can pause, then take some notes and re-watch about the topic to get a more understanding. Third, the students have a lot of time to do their task by collaborating with their friends. Then, the teachers can assist the students based on their needs and give more explanation to students who still have a problem in understanding the learning material.

The main advantages of flipped classroom are the learners have more time to learn and understand the material given, in addition they also have more chance to express and discuss the material that had been learned. According to Bergmann and Sams [18], there are several advantages of using flipped classroom. First, students get help on difficult topics. By the flipped classroom, the students can re-learn the material and review the instruction time after time. Thus, they can understand by themselves about what have to do about the assignment, the instructions, and the material. Second, flipped classroom enhances teacher-student interaction. By flipped classroom, the materials deliver through online so that the teacher has more time to interact in small groups with students or one-on-one. Simply, the teacher can talk or interact with the learners directly.

Flipped Classroom design is based on theory of Blomm's revised taxonomy of cognitive domain. This taxonomy provides six major categories of cognitive processes, strating from the bottom to the highest level. First, it is remembering: In this step, students recall or retrieve the information from the vidio about descriptive text at home or outside the classroom. Second, it is understanding. Students comprehend the meaning, interpret the information from the vidio and write a problem that they face when they learn from the vidio about descriptive text. Third, it is applying. Students identify and explore the descriptive text of the text to get the main idea. Fourth, it is analyzing. By using their critical thingking, students ask what happened, analyze the material or concept about descriptive text. Fifth, it is evaluating. Students make judgements and assessments about the value of ideas and the whole learning process, interpret and justify. And the last, it is creating. Students are able to make descriptive texs using their own words.

\section{METHOD}

Aquasi-experimental research was used as a design of this research. The tenth grade students of science class at SMAN 1 Kutacane registered in academic year 2020/2021 was the population of this research. There were seven classes in grade X which had 260 students. They were X IPA 1 to X IPA 7. In this research, X IPA 4 was the experimental class treated by applying flipped classroom and, X IPA 7 was the control class treated by applying conventional technique.

The instrument used to get the data was writing test. It was given after several times of treatment were done in both experimental and control class. The students were given several topics and asked to choose one of them to be developed into a descriptive text. Then, their writing was scored and used as the data of this research.

\section{Validity and Reliability of Research Instruments 3.1 Validity}

There were three validity testing of this research, they were: content validity, and face validity. To get the content validity, the test should be related to the materials that have been learned by the students based on the curriculum and syllabus. Gay, Mills, and Airasian [19] state that content validity refers to a test should be 
measured based on what the students have learned. Writing descriptive text is one of basic competencies in written form based on the syllabus of 2013 curriculum for the first semester of tenth grade level. Then, face validity is used to see the appropriateness of the form and layout of the instrument The researcher used Brown and Abeywickrama [20] scoring rubric to grade students' writing of descriptive text.

\subsection{Reliability}

The reliability is a way to measure the consistency of the students'score. Inter raters are needed in this reserach. According to Gay, Mills, and Airasian [20], inter-rater reliability is the consistency of two or more independent scorers, raters, or observers. There were two scorers in this research. The first scorer was the researcher himself, and the second scorer was the English teacher.

\section{DATA ANALYSIS TECHNIQUE}

\subsection{Descriptive analysis}

Descriptive analysis showed the result of the mean and the standard deviation score.

\subsection{Inferential Analysis}

There were three test used to analyze the data, they were normality, homogeneity, and hypothesis test. They were done to answer the question on problems formulation, whether there was a significant difference in students' achievement after treatment.

\subsubsection{Normality Test}

The test was conducted in order to find whether the distribution of the responses in the population were normal or not. It could be seen from the scores of posttest in both classes. One Sample Kolmogorov-Smirnov used to determine the level of significance.

\subsubsection{Homogeneity Test}

The purpose of the test was used to check whether the sample variance is homogeneous or not by using IBM SPSS version 20.0. The data was homogeneous if the level of significance is more than 0.05 .

\subsubsection{Hypothesis Test}

T-test was used to answer the hypothesis whether alternative hypothesis is accepted or rejected.

\section{RESULTS AND DISCUSSIONS}

The results found that the flipped classroom gave a significant effect on the students' writing skills after treatment. It could be seen from the significant difference of the mean scores and the standard deviation of the sample groups. Based on the analyzing of the post-tests result by using IBM SPSS version 20.0, the mean value of the post-test in experimental class was 85. 20, and in control class was 65.15 .

Table 1. Normality Test of Writing Test in Experimental and Control Classes

\begin{tabular}{|c|c|c|c|c|}
\hline Class & $\mathrm{N}$ & $\begin{array}{c}\text { Asymp.Sig. (2- } \\
\text { tailed) }\end{array}$ & Significance level & Conclusion \\
\hline Experimental & 25 & 0.074 & 0.05 & Normal \\
\hline Control & 34 & 0.008 & 0.05 & Normal \\
\hline
\end{tabular}

Based on the data above, the value of asymp.Sig. (2tailed) in experimental class was 0.074 which was higher than the value of significance level 0.05 . Then, the value of asymp.Sig. (2-tailed) in control class was 0.008 which was also higher than the value of significance level 0.05 . Thus, the students' writing skill scores in both classes were normally distributed.

Table 2. Homogeneity Test of Writing Test in Experimental and Control Classes

\begin{tabular}{|c|c|c|c|}
\hline Data & Based on sig. & Significance Level & Conclusion \\
\hline Writing test & 0.481 & 0.05 & Homogeneous \\
\hline
\end{tabular}

Based on the table of homogeneity test above, the students' writing skill score was homogeneous since the Table 3. Result of t-test Analysis of Students Writing Skill in Experimental and Control Classes

\begin{tabular}{|l|l|l|}
\hline \multirow{2}{*}{ Classification } & \multicolumn{2}{c|}{ Class } \\
\cline { 2 - 3 } & \multicolumn{1}{|c|}{ Experimental } & \multicolumn{1}{c|}{ Control } \\
\hline $\mathrm{N}$ & 25 & 65.15 \\
\hline Mean & 85.20 & 11.45 \\
\hline Dev Stand & 5.86 & \\
\hline $\mathrm{t}_{\text {observed }}$ & 11.952 & \\
\hline $\mathrm{t}_{\text {table }}$ & 4.01 & \\
\hline
\end{tabular}

value of significance of writing test was 0.481 which was higher than the level of significance 0.05 . 
Based on the data in the table above, the value of $t_{\text {observed }}$ was higher than $t_{\text {table }}\left(t_{\text {observed }}>t_{\text {table }}\right)$. Because $t_{\text {observed }}$ was higher than $t_{\text {table, }}$ it was indicated that $\mathrm{H}_{\mathrm{a}}$ was accepted, and $\mathrm{H}_{\mathrm{o}}$ was rejected. It could be concluded that the students who were taught by using flipped classroom had significant effect on the students' writing skill than the students who were taught by using conventional technique. The mean score of writing skill in the table above, it was found that flipped classroom got higher mean score which was 85.20 than conventional technique that was 65.15 . It could be concluded that alternative hypothesis was accepted because $t_{\text {observed }}(11.952)$ was higher than $t_{\text {table }}$ (4.01). Based on the data analysis, it was found that the

students who were taught by using flipped classroom got higher score in writing skill than the students who were taught by using conventional tehnique.

The result of hypothesis showed that flipped classroom affected students' writing skill on descriptive text to get higher result than conventional technique in the tenth students of science class at SMAN 1 Kutacane. There were many students who got good score in writing test because they could explore their higher order thinking skill in writing, and discuss everything in online group discussion through WA Group. Then, the students had more time to discuss their writing with their friends and the teacher so that they are able to enhance their skill in writing. In a line with, Bergmann and Sams [19] mention the advantages of using flipped classroom. They are students get help on difficult topics, they can re-learn the material and review the instruction time after time, they can understand by themselves about what have to do about the assignment, the instructions, and the material. Then, flipped classroom enhances teacher-student interaction. By flipped classroom, the materials deliver through online so that the teacher has more time to interact in small groups with students or one-on-one.

This research had the same results with the previous researches stated that the students of the experimental group performed better on the writing than the students of the control group. In short, flipped classroom provides a significant effect on the ability of the students to write descriptive text that can be applied by the teachers in teaching writing.

\section{CONCLUSION}

The students taught by using flipped classroom had significant effect to their writing than those who were taught by using conventional technique in the tenth grade students of science class of SMAN 1 Kutacane. The result of this research had some implications in teaching English, especially teaching writing. Flipped classroom is really efective for the English teachers to be implemented in their classroom because they have a lot of time to interact with their students to improve students' writing skill.

\section{ACKNOWLEDGMENT}

I thank to those who given their contribution to my research. My deepest gratitude goes to Asri Nainggolan, S. Pd., and Rima Melati, S. Pd., as the English teachers of SMAN 1 Kutacane who helped and given me a great deal of time, guidance and valuable pieces of advice for my research.

\section{REFERENCES}

[1]Priyana, J. (2008). Scaffolding English for Junior High School Students. Jakarta: Pusat Pembukuan, Departemen Pendidikan Nasional.

[2]Oshima, A., \& Hogue, A. (1999). Writing Academic English (Third Edition). New York: Longman.

[3]Ekmekci, E. (2017). The Flipped Writing Classroom in Turkish EFL Context: A Comparative Study on a New Model. Turkish Online Journal of Distance Education- TOJDE, 18, 151-167.

[4]Bishop \& Veleger. (2013). The Flipped Classroom: A Survey of the Research.

[5]Çevikbaş, M., \& Argün, Z. (2017). An Innovative Learning Model in Digital Age: Flipped Classroom. Journal of Education and Training Studies, 5, 189 200.

[6]Elfatah, M. A., and Ahmed, A. S. (2016). The Effect of Flipping Classroom on Writing Skill in English as a Foreign Language and Students' Attitude towards Flipping. China Foreign Language, 14, $98-114$.

[7]Afrilyasanti, R., Cahyono, B. Y., \& Astuti, U. P. (2016). Effect of Flipped Classroom Model on Indonesian EFL Students' Writing Ability Across and Individual Differences in Learning. International Journal of English Language and Linguistics Research, 4(5), 65-81.

[8]Soltanpour, F., \& Valizadeh, M. (2018). A Flipped Writing Classroom: Effects on EFL Leaners' Argumentative Essays. Advances in Language and Literary Studies (ALLS), 9(1), 5- 13.

[9]Langan, John. (2011). College Writing Skill with Reading. Singapore: McGraw Hill.

[10]Brown, H. D. (2000). Teaching by Principles: An Interactive Approach to Language Pedagogy (Second Edition). San Francisco: Longman.

[11]Lindsay, C., \& Knight, P. (2006). Learning and Teaching English: A Course for Teachers. Oxford: Oxford University Press.

[12]Gerrot, L., \& Wignel, P. (1998). Making Sense of Functional Grammar : An Introductory of Workbook. Australia : Gred Stabler AEE.

[13]Wardani, I., (2014). "Improving the Ability of Students in Writing Descriptive Text Through Guided-Question Technique." Skripsi Unpublished. Palu: Universitas Tadulako (e-Journal of English 
Language Teaching Society (ELTS) Vol. 2 No. 1 2014 - ISSN 2331-1841).

[14]Danker, B. (2005). Using flipped classroom approach to explore deep learning in large classrooms. The IAFOR Journal of Education, 3 (1).

[15]Bretzmann. (2013). Flipping 2.0: Practical Strategies for Flipping Your Class.

[16]Krathwohl, D R. (2002). A Revision of Bloom's Taxonomy: An Overview. Theory Into Practice, The Ohio State University.

[17]Walsh, Kelly. (2013). Flipped Classroom Workshop in a Book: Learn How to Implement Flipped Instruction in Your Classroom.

[18]Bergmann, J., \& Sams, A. (2012). Flip Your Classroom: Reach Every Student in Every Class Every Day. Washington DC: International Society for Technology in Education, 120-190.

[19]Gay, L. R, Mills, G. E., \& Airasian, P. (2011). Educational Research: Competencies for Analysis and Application (Tenth Edition). Boston: Pearson Education, Inc.

[20]Brown, H. D., \& Abeywickrama, P. (2010). Language Assessment: Principles and Classroom Practices. New York: Pearson Education. 